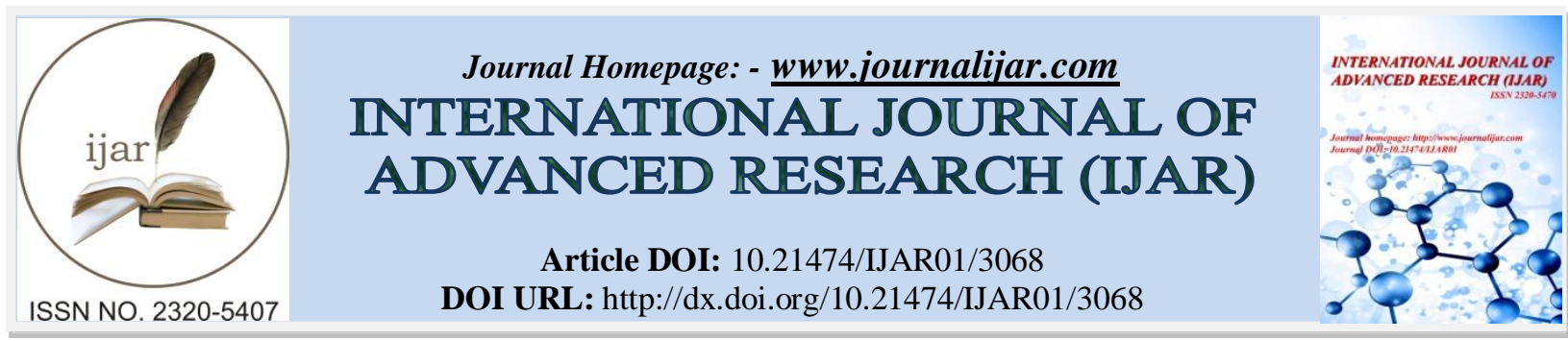

RESEARCH ARTICLE

\title{
DIABETIC PATIENTS KNOWLEDGE, ATTITUDE AND PRACTICE TOWARD PERIODONTAL HEALTH.
}

Dr. Abdel Rahman Murtada Abdel Rahman Ramadan', Abdulrahman Hisham Abdulrahman Almadani ${ }^{2}$, Omar Obaidallah Mubarak Aljohani ${ }^{3}$ and Khalid Ahmad Azali Amara ${ }^{4}$.

1. BDS, MSc., PhD, FSMSB (Hon).Associate Professor of Periodontology and Oral medicine. Consultant of Periodontology. Taibah University College of Dentistry, Departments of Basic and Clinical Dental Sciences and Preventive Dental Sciences Al-Madinah Al-Munawarah.

2. Dental intern in Taibah University College of Dentistry. A.N: 3100123.

3. Second grade Resident, Endocrinology, Public Health.

4. MD. Dr.PH, Associate Professor Public Health \& Community Medicine, Faculty of Medicine - BSU - Egypt, College of Dentistry Taibah University, Vice Dean For Quality, Development \& International Affairs, Certified Trainer for International Research Ethics.

\section{Manuscript Info}

\section{Manuscript History}

Received: 03 December 2016

Final Accepted: 30 December 2016

Published: January 2017

\section{Abstract}

This paper provides the results of analysis of total, sectoral-specific, and spatial-specific multipliers and flow-on effects in Sumatera Island economy. The model employed was Inter-Regional Input-Output Model (IRIOM) developed using new hybrid procedures with special attention on Island economy. Data used for model were updated Indonesian data for the year of 2015. The results show that firstly, the important sectors of Java Island economy could be based on total multipliers and flow-on effects of output, income and employment. Secondly, important economic sectors could be based on sector-specific multipliers effects; multipliers that occurred in own sector and other sectors. Thirdly, important economic sectors could be based on spatialspecific multipliers; multipliers that occurred both in own region and other regions. Fourthly, important economic sectors could be based on spatial distribution of flow-on; flow-on effects that occurred in own region as well as in other regions.

Copy Right, IJAR, 2016,. All rights reserved.

\section{Introduction:-}

Diabetes Mellitus (DM), the commonest endocrine disorder. Oral diseases are common in diabetics as compared to non-diabetic's individuals. Despite the global acknowledgment of the risk of Diabetes Mellitus, diabetic patients' knowledge and attitude toward their increased risk for oral health has not been fully deal with. Oral hygiene behaviourand seeking oral health care depends on a number of factors. Lack of knowledge about dental health and conforming to better oral hygiene is among the causes for non-adherence to oral hygiene practices, economical limitations, lack of services and lack of proper counselling.

Diabetes Mellitus refers to a group of common metabolic disorders that share the phenotype of sustained hyperglycaemia affecting almost all tissues in the body including those in the oral cavity. It is associated with

Corresponding Author:- Dr.Abdel Rahman Murtada Abdel Rahman Ramadan.

Address:- BDS, MSc., PhD, FSMSB (Hon).Associate Professor of Periodontology and Oral medicine.

Consultant of Periodontology. Taibah University College of Dentistry, Departments of Basic and

Clinical Dental Sciences and Preventive Dental Sciences Al-Madinah Al-Munawarah . 
aberrations in carbohydrate, fat, and protein metabolism, and results of numerous chronic complications, comprising of microvascular, macrovascular, and neuropathic disorders (4).

\section{Aims and objectives:-}

The aim of this study is to gather baseline information on knowledge, attitude, and practices of diabetic patients regarding their oral health with the view of enhancing dental health education for them, which will help in updating their knowledge about the disease and the various oral complications and to assess their attitudes and practices toward sustaining good oral health through proper oral hygiene and regular dental check-ups.

\section{Material and Method:-}

This study was a cross-sectional Analytic of 416 diabetic patients visiting the Prince Abdulaziz Bin Majed Diabetic Centre (PABMDC). Eligible participants will be confirmed diabetes mellitus patients who can read and write.

A questionnaire will be designed to assess the knowledge, attitude, and practices of diabetic patients along with corresponding demographic variables.

Questionnaire questions were carefully selected from relevant published reports in international journals. The questionnaire questions will be related to participants' nationality, age and gender, Type and duration of diabetes, and their awareness for systemic and oral diseases as complications associated with diabetes

The questionnaire will be piloted in 416 patients to determine its validity.

\section{Result:-}

The majority of the subjects were Saudis $99.6 \%, 99.8 \%$ and diagnosed with diabetes more than 6 months ago, $62.9 \%$ male and $37.1 \%$ female with mean age of 44.91 (Table 8 ). $31.4 \%$ of the subjects visited the dentist in the past 12 months for fillings, $2.9 \%$ for $\mathrm{C} \& \mathrm{~B}, 23.1 \%$ for restorations, $48.8 \%$ for checkup, $18.5 \%$ for RCT, $18.7 \%$ for periodontal therapy, $11.6 \%$ for dental extractions and $9 \%$ for other reasons (Table 1). And the majority of them said that Tooth brushing \& toothpaste is their oral hygiene method (Table 3). $7.9 \%$ of the subjects never brush their teeth (Table 4) and $46.6 \%$ said that tooth brushing is their Health promotion priority (Table 6), 18.2\% of the subjects said that the reason for not visiting the dentist more often is the difficulty in scheduling an appointment, 38\% said because of high coast, $24.4 \%$ said because they forgot, $23.1 \%$ because they don't like their dentist, 28.8 because of anxiety $26.4 \%$ because of transport problems and $12.1 \%$ because they can't leave work (Table 2 ).

Vast majority of the subjects have gingival bleeding $99.6 \%$ (Table 5). 50.8\% think diabetic more prone to oral diseases (Table 7). 50.5\% of the subjects have been told by their physician about the oral problems related to diabetes (Table 9), moreover $49.2 \%$ of them think that their oral problems are because of diabetes (Table 10).

Table 1: visited a dentist visit at least once in the previous 12 months

\begin{tabular}{|c|c|c|c|c|c|c|c|c|c|c|c|c|c|c|c|c|}
\hline \multicolumn{17}{|c|}{ Have you visited a dentist visit at least once in the previous 12 months } \\
\hline & \multicolumn{2}{|c|}{ Fillings } & \multicolumn{2}{|c|}{$\mathrm{C} \& \mathrm{~B}$} & \multicolumn{2}{|c|}{ Restoration } & \multicolumn{2}{|c|}{ Checkup } & \multicolumn{2}{|c|}{ RCT } & \multicolumn{2}{|c|}{$\begin{array}{c}\text { Dental } \\
\text { extraction }\end{array}$} & \multicolumn{2}{|c|}{$\begin{array}{c}\text { Periodontal } \\
\text { therapy }\end{array}$} & \multicolumn{2}{|c|}{ Other } \\
\hline & $\begin{array}{c}\text { Freq } \\
\text { uenc } \\
y\end{array}$ & $\%$ & $\begin{array}{c}\text { Freq } \\
\text { uenc } \\
y\end{array}$ & $\%$ & $\begin{array}{c}\text { Freq } \\
\text { uenc } \\
y\end{array}$ & $\%$ & $\begin{array}{c}\text { Freq } \\
\text { uenc } \\
y\end{array}$ & $\%$ & $\begin{array}{l}\text { Freq } \\
\text { uenc } \\
y\end{array}$ & $\%$ & $\begin{array}{c}\text { Freq } \\
\text { uenc } \\
y\end{array}$ & $\%$ & $\begin{array}{c}\text { Freq } \\
\text { uenc } \\
y\end{array}$ & $\%$ & $\begin{array}{c}\text { Freq } \\
\text { uenc } \\
y\end{array}$ & $\%$ \\
\hline $\begin{array}{l}\text { Y } \\
\text { es }\end{array}$ & 143 & $\begin{array}{l}3 \\
1\end{array}$ & 95 & $\begin{array}{l}2 \\
0\end{array}$ & 105 & $\begin{array}{l}2 \\
3 \\
1\end{array}$ & 222 & $\begin{array}{l}4 \\
8\end{array}$ & 84 & $\begin{array}{l}1 \\
8\end{array}$ & 53 & $\begin{array}{l}1 \\
1\end{array}$ & 85 & $\begin{array}{l}1 \\
8\end{array}$ & 41 & $\begin{array}{l}9 \\
0\end{array}$ \\
\hline $\begin{array}{l}\mathrm{N} \\
\mathrm{o}\end{array}$ & 312 & $\begin{array}{l}6 \\
8\end{array}$ & 360 & $\begin{array}{l}7 \\
9\end{array}$ & 350 & $\begin{array}{l}7 \\
6 \\
9\end{array}$ & 233 & $\begin{array}{l}5 \\
1\end{array}$ & 371 & $\begin{array}{l}8 \\
1\end{array}$ & 402 & $\begin{array}{l}8 \\
8\end{array}$ & 370 & $\begin{array}{l}8 \\
1\end{array}$ & 414 & $\begin{array}{l}9 \\
1\end{array}$ \\
\hline
\end{tabular}


Table 2:- reason(s) for NOT visiting the dentist

\begin{tabular}{|c|c|c|c|c|c|c|c|c|c|c|c|c|c|c|c|c|}
\hline \multicolumn{17}{|c|}{ What is/are the reason(s) for NOT visiting the dentist more often } \\
\hline & \multicolumn{2}{|c|}{$\begin{array}{l}\text { Difficulty } \\
\text { in } \\
\text { scheduling } \\
\text { appointme } \\
\text { nt }\end{array}$} & \multicolumn{2}{|c|}{ costs } & \multicolumn{2}{|c|}{ Forgot } & \multicolumn{2}{|c|}{$\begin{array}{l}\text { Don't like } \\
\text { my dentist }\end{array}$} & \multicolumn{2}{|c|}{$\begin{array}{l}\text { Fear or } \\
\text { anxiety }\end{array}$} & \multicolumn{2}{|c|}{$\begin{array}{l}\text { Transportat } \\
\text { ion } \\
\text { problems }\end{array}$} & \multicolumn{2}{|c|}{$\begin{array}{c}\text { I can't } \\
\text { leave work }\end{array}$} & \multicolumn{2}{|c|}{ Other } \\
\hline & $\begin{array}{l}\text { Frequ } \\
\text { ency }\end{array}$ & $\%$ & $\begin{array}{l}\text { Frequ } \\
\text { ency }\end{array}$ & $\%$ & $\begin{array}{l}\text { Frequ } \\
\text { ency }\end{array}$ & $\%$ & $\begin{array}{l}\text { Frequ } \\
\text { ency }\end{array}$ & $\%$ & $\begin{array}{l}\text { Frequ } \\
\text { ency }\end{array}$ & $\%$ & $\begin{array}{l}\text { Frequ } \\
\text { ency }\end{array}$ & $\%$ & $\begin{array}{l}\text { Frequ } \\
\text { ency }\end{array}$ & $\%$ & $\begin{array}{l}\text { Frequ } \\
\text { ency }\end{array}$ & $\%$ \\
\hline $\begin{array}{l}\mathrm{Y} \\
\text { es }\end{array}$ & 83 & $\begin{array}{l}18 \\
.2\end{array}$ & 173 & $\begin{array}{c}38 \\
.0\end{array}$ & 111 & $\begin{array}{r}24 \\
.4\end{array}$ & 105 & $\begin{array}{c}23 \\
.1\end{array}$ & 131 & $\begin{array}{c}28 \\
.8\end{array}$ & 120 & $\begin{array}{c}26 \\
.4\end{array}$ & 55 & $\begin{array}{l}12 \\
.1\end{array}$ & 30 & $\begin{array}{l}6 . \\
6\end{array}$ \\
\hline $\begin{array}{c}\mathrm{N} \\
\mathrm{O}\end{array}$ & 372 & $\begin{array}{r}81 \\
.8 \\
\end{array}$ & 282 & $\begin{array}{r}62 \\
.0 \\
\end{array}$ & 344 & $\begin{array}{l}75 \\
.6\end{array}$ & 350 & $\begin{array}{c}76 \\
.9\end{array}$ & 324 & $\begin{array}{l}71 \\
.2 \\
\end{array}$ & 335 & $\begin{array}{l}73 \\
.6 \\
\end{array}$ & 400 & $\begin{array}{r}87 \\
.9 \\
\end{array}$ & 425 & $\begin{array}{r}93 \\
.4 \\
\end{array}$ \\
\hline
\end{tabular}

Table 3:- oral hygiene method

\begin{tabular}{|c|c|c|c|c|c|c|c|c|c|c|}
\hline \multicolumn{11}{|c|}{ What is your oral hygiene method } \\
\hline & \multicolumn{2}{|c|}{$\begin{array}{c}\text { Tooth brushing \& } \\
\text { toothpaste }\end{array}$} & \multicolumn{2}{|c|}{$\begin{array}{c}\text { Use of dental floss } \\
\text { at least once a } \\
\text { week }\end{array}$} & \multicolumn{2}{|c|}{$\begin{array}{l}\text { Use of dental floss } \\
\text { at least once a day }\end{array}$} & \multicolumn{2}{|c|}{ Miswak } & \multicolumn{2}{|c|}{ Use of sticks } \\
\hline & Frequency & $\%$ & Frequency & $\%$ & Frequency & $\%$ & Frequency & $\%$ & Frequency & $\%$ \\
\hline Yes & 313 & 68.8 & 87 & 19.1 & 93 & 20.4 & 114 & 25.1 & 42 & 9.2 \\
\hline No & 142 & 31.2 & 368 & 80.9 & 362 & 79.6 & 341 & 74.9 & 413 & 90.8 \\
\hline
\end{tabular}

Table 4:- Frequency of tooth brushing

\begin{tabular}{|c|c|c|}
\hline \multicolumn{2}{|c|}{ How many time do you brush your teeth } & $\%$ \\
\hline & Frequency & 7.9 \\
\hline Never & 36 & 28.8 \\
\hline Once a day & 131 & 35.4 \\
\hline Twice a day & 161 & 14.9 \\
\hline Three times a day & 68 & 5.7 \\
\hline four times a day & 26 & 7.3 \\
\hline
\end{tabular}

Table 5:- Gingival bleeding

\begin{tabular}{|c|c|cc|}
\hline \multicolumn{3}{|c|}{ Does your gingivae bleed } & $\%$ \\
\hline & Frequency & 99.6 \\
\hline yes & 453 & .4 \\
\hline
\end{tabular}

Table 6:- Health promotion priorities

\begin{tabular}{|c|c|c|c|c|c|c|c|c|}
\hline \multicolumn{8}{|c|}{ What are your health promotion priorities which have been done in the past year } \\
\hline & Healthy diet & Brush teeth regularly & Visit a dentist regularly & \multicolumn{2}{c|}{ Visit a doctor regularly } \\
\hline & Frequency & $\%$ & Frequency & $\%$ & Frequency & $\%$ & Frequency & $\%$ \\
\hline Yes & 128 & 28.1 & 212 & 46.6 & 122 & 26.8 & 55 & 12.1 \\
\hline No & 327 & 71.9 & 243 & 53.4 & 333 & 73.2 & 400 & 87.9 \\
\hline
\end{tabular}

Table 7:- Health promotion priorities

\begin{tabular}{|c|c|c|}
\hline \multicolumn{2}{|c|}{ Is a diabetic more prone to oral diseases } & $\%$ \\
\hline & Frequency & 50.8 \\
\hline yes & 231 & 39.1 \\
\hline no & 178 & 10.1 \\
\hline
\end{tabular}


Table 8:- Age

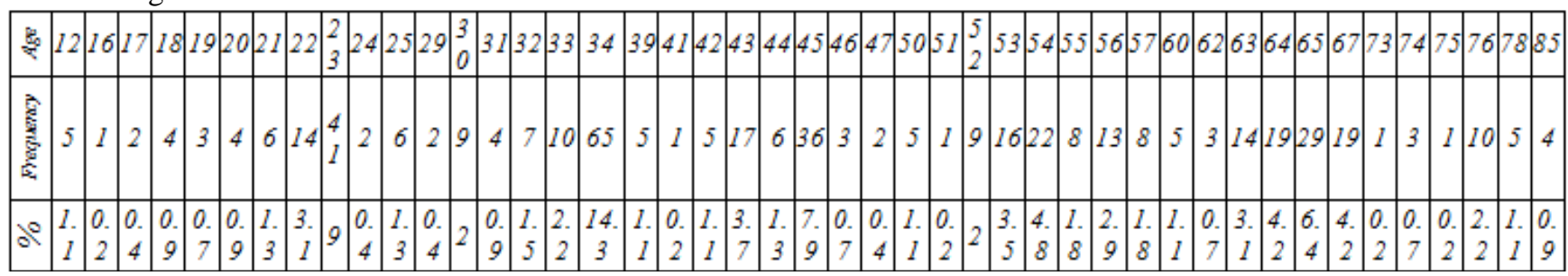

Table 9:- Told by physician about the oral problems related to diabetes

\begin{tabular}{|c|c|c|}
\hline \multicolumn{3}{|c|}{ Did your physician tell you about the oral problems related to diabetes } \\
\hline & Frequency & $\%$ \\
\hline yes & 230 & 50.5 \\
\hline no & 183 & 40.2 \\
\hline Don't know & 42 & 9.2 \\
\hline
\end{tabular}

Table 10:- Do you think that your dental/oral problems are because of diabetes

\begin{tabular}{|c|c|c|}
\hline \multicolumn{3}{|c|}{ Do you think that your dental/oral problems are because of diabetes } \\
\hline & Frequency & $\%$ \\
\hline yes & 224 & 49.2 \\
\hline no & 157 & 34.5 \\
\hline Don't know & 74 & 16.3 \\
\hline
\end{tabular}

\section{Discussion:-}

This cross sectional analytic study of 456 diabetic patients visiting Prince Abdulaziz Bin Majed Diabetic Center (PMBADC) located in Al Madinah, Saudi Arabia. Dent Hyg said that 78.7\% of the subject visited a dentist for check-up in the past 12 months and $22.2 \%$ brush their teeth twice a day and $73.6 \%$ never use dental floss, $80 \%$ visited a physician in the past year and $12.6 \%$ visited a dentist (1). While Diabetes Res ClinPract. Said $42.7 \%$ of participants reported visiting a dentist for a regular check-up, and $58.6 \%$ went to see a dentist last year. Of the participants, $95.3 \%$ brushed teeth at least once a day and $61.2 \%$ brushed at least twice a day; $34.9 \%$ flossed their teeth at least once a day and $35.3 \%$ never flossed (2).

Inpresent study $48.8 \%$ of the subject visited a dentist for check-up in the past 12 months and $35.4 \%$ brush their teeth twice a day and $79.6 \%$ never use dental floss, $12.1 \%$ visited a physician in the past year and $26.8 \%$ visited a dentist and $28.8 \%$ brushed teeth at least once a day and $20.4 \%$ flossed their teeth at least once a day.

\section{Limitations:-}

We acknowledge that the sample in this study is a convenience sample which may or may not represent the diabetes population Nevertheless, it should be noted that oral health behaviors in the present study are similar to those reported in the literature (3). There are some potential limitations in this study that should be considered when interpreting the results. First, since the study was a analytical cross-sectional study, therefore, no direct relationship between variables and outcomes can be proved. A second limitation is the potential reporting bias associated with the self-administered questionnaire with the possibility that subjects tend to over-report compliance Also, to get some participants respond was difficult especially diabetics who are not registered in (PMBADC). Another potential limitation is the use of a lot close-ended questions (i.e. yes/no/don't know) in the oral health knowledge test may allow participants to guess the correct answer.

\section{Conclusion:-}

The subjects are well aware about their diabetic Bot/ADC

Conditions and the oral effects of diabetes, on the other hand, they have near to the ground attitude and practice (behavior) towered systemic and oral health. 


\section{Recommendations:-}

Health professionals have the opportunity to educate patients with diabetes about oral manifestations (e.g., dry mouth) and complications (e.g., periodontitis and oral candidiasis) of diabetes and to promote proper oral health behaviors. They should provide appropriate special oral care information and advice concerns related to dental hygiene. In addition to the routine education of patients with diabetes about the importance of proper oral hygiene and receiving regular professional dental care, health professionals should educate patients more about oral complications related to diabetes and measures that can be taken to prevent these oral complications such as avoiding tobacco use.

\section{Acknowledgement:-}

The authors thank the physician: Dr.Somayah A. Assaedii, Dr. Tamer Hifnawyii. This study was completed with support from College of dentistry in Taibah University, Taibah medical club in Taibah University and Prince Abdulaziz Bin Majed Diabetic Centre (PMBADC) located in Al Madinah, Saudi Arabia.

\section{References:-}

1. J Dent Hyg. Diabetes-Related Knowledge and Sources of Information among Periodontal Patients: Is There a Role for Dental Hygienists?.2013 Apr; 87(2): 82-89.

2. Diabetes Res ClinPract. Oral Health Knowledge and Behavior among Adults with Diabetes.2009 Dec; 86(3): 239-246.

3. Macek MD, Taylor GW, Tomar SL. Dental care visits among dentate adults with diabetes, United States, 2003. J Public Health Dent. 2008;68:102-110. 